\title{
Skin Tattoo
}

National Cancer Institute

\section{Source}

National Cancer Institute. Skin Tattoo. NCI Thesaurus. Code C113681.

A permanent mark created by the insertion of pigment below the skin. 